\title{
Research
}

\section{The role of the Quality and Outcomes Framework in the care of long-term conditions:}

\author{
a systematic review
}

\begin{abstract}
\section{Background}

Improving care for people with long-term conditions is central to NHS policy. It has been suggested that the Quality and Outcomes Framework (QOF), a primary care pay-forperformance scheme that rewards practices for delivering effective interventions in long-term conditions, does not encourage high-quality care for this group of patients.
\end{abstract}

\section{Aim}

To examine the evidence that the QOF has improved quality of care for patients with longterm conditions.

\section{Design and setting}

This was a systematic review of research on the effectiveness of the QOF in the UK.

\section{Method}

The authors searched electronic databases for peer-reviewed empirical quantitative research studying the effect of the QOF on a broad range of processes and outcomes of care, including coordination and integration of care, holistic and personalised care, self-care, patient experience, physiological and biochemical outcomes, health service utilisation, and mortality. Because

the studies were heterogeneous, a narrative synthesis was carried out.

\section{Results}

The authors identified three systematic reviews and five primary research studies that met the inclusion criteria. The QOF was associated with a modest slowing of both the increase in emergency admissions and the increase in consultations in severe mental illness (SMI), and modest improvements in diabetes care. The nature of the evidence means that the authors cannot be sure that any of these associations is causal. No clear effect on mortality was found. The authors found no evidence that the QOF influences integration or coordination of care, holistic care, self-care, or patient experience.

\section{Conclusion}

The NHS should consider more broadly what constitutes high-quality primary care for people with long-term conditions, and consider other ways of motivating primary care to deliver it.

\section{Keywords}

incentive reimbursement; primary health care; quality indicators, health care; quality of health care.

\section{INTRODUCTION}

The UK's Quality and Outcomes Framework (QOF) is the world's largest pay-forperformance scheme in primary care. It rewards general practices financially for delivering interventions and achieving patient outcomes using evidence-based indicators developed by the National Institute for Health and Care Excellence (NICE).' Although the QOF is voluntary, nearly $99 \%$ of practices in England participate, on average deriving $10-15 \%$ of total practice income from the scheme.

The introduction of the QOF in 2004 was a part of a new national contract for GPs, driven by the need to respond to years of underinvestment in general practice compared with other parts of the health service, low morale among GPs, and variations in the quality of primary medical care. ${ }^{3,4}$ The QOF was intended to provide a mechanism to motivate GPs and to increase funding for their practices, and the vast majority of practices took up the opportunity for additional income. Evidence from the early years of the scheme suggested it reduced variations between practices in the delivery of incentivised interventions, and contributed to progress towards better use of electronic records and nurseled multidisciplinary care of long-term conditions. ${ }^{3}$ After the first year of the QOF most practices achieved near-maximum remuneration from the scheme.

Arguably, then, the QOF achieved what it set out to do. But this may have come at a

LJL Forbes, MSc, MD, FFPH, senior clinical research fellow; C Marchand $\mathrm{PhD}$, research assistant; S Peckham, MA, HMFPH, professor of health policy, Centre for Health Services Studies, University of Kent, Canterbury, Kent. T Doran, MPH, MD, MFPH, professor of health policy, Department of Health Sciences, University of York, York.

\section{Address for correspondence}

Lindsay JL Forbes, Centre for Health Services cost. It has been suggested that practices prioritise QOF-related activities at the expense of other aspects of care, because of their reliance on QOF income. ${ }^{6,7}$

A decade after the introduction of the QOF, NHS strategy, set out in the 2014 Five Year Forward View, is now focused on other challenges. These include finding new ways to manage people with longterm conditions, whose care is estimated to consume $70 \%$ of health service resources. ${ }^{8}$ Most clinical QOF indicators relate to the care of long-term conditions and are based on good evidence, ${ }^{4}$ but tend to be limited in scope, focusing on single, biomedical dimensions of care. Appendix 1 provides a brief description of the 68 QOF indicators relating to care of long-term conditions in 2016-2017; the total number of indicators for that year was 77

In 2015, the Royal College of General Practitioners called for the replacement of the QOF to allow GPs to focus on providing the best possible holistic care.? NHS England, in April 2016, undertook to review the QOF, acknowledging that it may have 'served its purpose' and may be 'a barrier to holistic management'.10 In early 2017, the British Medical Association called for the QOF to be suspended to reduce bureaucratic pressures and free up clinical time. ${ }^{11}$ Scotland abolished the QOF in $2016 .^{3}$

The Policy Research Unit in Commissioning and the Health Care System was commissioned to undertake a review, led by the Centre for Health Services

Studies, George Allen Wing, Cornwallis Building, University of Kent, Canterbury, Kent, CT2 7NF, UK.

E-mail: L.Forbesakent.ac.uk

Submitted: 10 March 2017; Editor's response: 10 April 2017; final acceptance: 12 May 2017. (c)British Journal of General Practice This is the full-length article (published online 26 Sep 2017) of an abridged version published in print. Cite this version as: Br J Gen Pract 2017; DOI: https://doi.org/10.3399/bjgp17X693077 


\section{How this fits in}

The usefulness of the Quality and Outcomes Framework (QOF) as a tool for promoting progress towards the vision of the Five Year Forward View for care of long-term conditions has been questioned. This systematic review found no convincing evidence that the QOF can promote better integrated care, personalised, holistic care, or self-care - or, indeed, improve any other outcomes in people with long-term conditions. The NHS should consider other ways of supporting general practice to deliver the vision of the Five Year Forward View.

Studies at the University of Kent, to report in September 2016. The authors aimed to examine the evidence that the QOF has improved care and outcomes for patients with long-term conditions, including elements of care highlighted as priorities in the Five Year Forward View, ${ }^{8}$ such as coordinated and integrated care, holistic and personalised care, and self-care.

\section{METHOD}

The authors searched for reports of empirical quantitative research examining the effectiveness of the QOF in the management of long-term conditions, published in peerreviewed journals in English. They included studies of populations registered with GPs in the UK, and excluded studies of locally designed and implemented pay-forperformance schemes, and studies of limited geographical scope Iwhich were defined as examining data from fewer than four primary care trusts in England, or fewer than 100 practices in Scotland) because of likely low generalisability. The authors included studies where the comparator was any other method of funding general practice, concurrent or historical, and, if there was no concurrent comparator, where the analysis controlled for underlying trends. They set no limits on outcomes except that they were measured quantitatively and related to patients with long-term conditions, including

- measures of health or morbidity: biochemical and physiological measures, mortality, hospital admissions;

- biomedical aspects of delivery of care: diagnostics, plans, referrals, and ongoing monitoring, clinical interventions (for example, prescriptions, immunisations), consultation rates;

- broader aspects of care: coordination, continuity or integration of care, holistic care (that is, that considers multiple morbidity and social context, personalised for the patient), self-care; and

- patient perspectives: patient experience, quality of life, or satisfaction.

The authors included randomised controlled trials, longitudinal studies where the analysis attempted to control for underlying trends, controlled beforeand-after studies, and systematic reviews of these. They excluded cross-sectional studies examining how outcomes varied according to QOF achievement, because of the lack of suitable controls, the nearuniversal high level of achievement, and the high likelihood of confounding of associations between QOF achievement and outcome by other factors. The authors also excluded studies in which the researchers estimated or modelled outcomes rather than reporting empirical data (more details of the inclusion and exclusion criteria are available from the authors). The authors searched electronic databases /Cochrane Database, Medline, Embase, and Health Management Information Consortium) for studies published between 2004 (the year the QOF was introduced) and May 2016 (see Box 1 for search terms). They examined references of identified papers to search for further reports and asked experts for references to other relevant research.

Two of the authors assessed suitability for inclusion for each abstract identified, and, where there was no consensus, asked a third author to adjudicate. Data were extracted independently from all papers by two authors.

The authors assessed quality of randomised controlled trials using adaptations of the Cochrane Collaboration's tool, ${ }^{12}$ and longitudinal studies and systematic reviews using tools adapted from those developed by the National Institutes of Health. 13,14

\section{RESULTS}

Identification and description of studies

Figure 1 shows the process of identification of studies. The three most recent systematic reviews asking the same questions as this review had search dates in 201215,16 and 2015.17 These included 20 studies of the QOF in total. ${ }^{18-37}$ The systematic review with the 2015 search date ${ }^{17}$ identified two studies of the QOF,22,32 both of which had been published in 2011 and had been included in one or other of the two reviews with search dates in 2012.

In all three reviews, while the authors set 


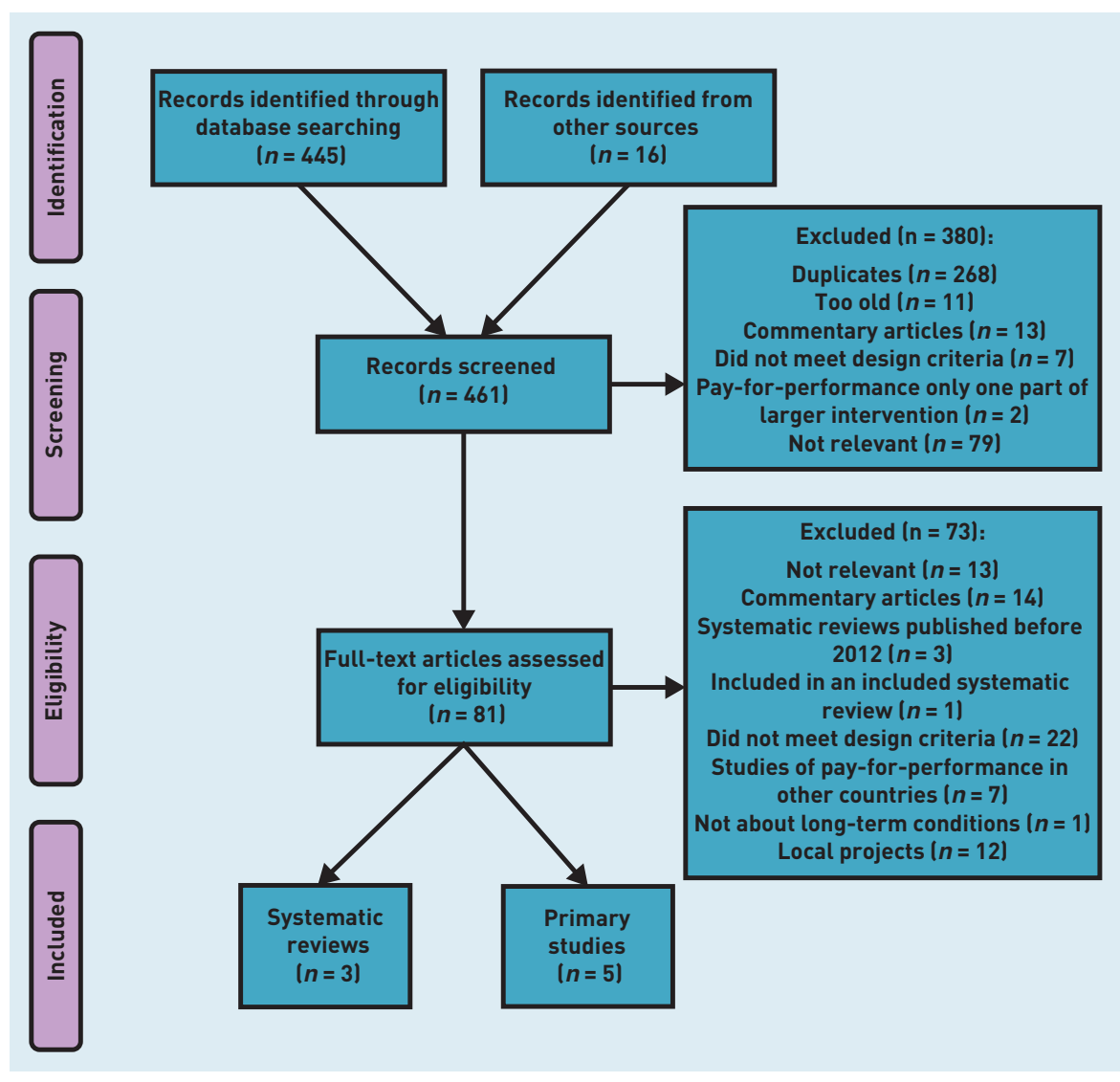

Figure 1. Search process and results. few limits on outcomes, study outcomes were solely derived from either QOF indicators themselves or prescribing data, with two exceptions: one study examined adherence to British Thoracic Society spirometry standards ${ }^{36}$ and the other cardiovascular events in patients with hypertension. ${ }^{32}$

The authors found five primary research studies meeting the search criteria published since 2012. ${ }^{38-42}$ The first examined trends in mortality rates for conditions covered by the QOF, comparing the UK with other high-income countries with no pay-for-performance schemes in primary care. ${ }^{38}$ The others examined the effect of introducing the QOF on patient management and outcomes, either nationally, ${ }^{39}$ or in samples of practices participating in the UK General Practice Research Database (GPRD) or Clinical Practice Research Datalink (CPRD) (627 UK practices ${ }_{10}^{40} 516$ UK practices, ${ }^{41} 148$ English practices $^{42}$ ).

The studies' outcomes were: mortality from long-term conditions; ${ }^{38}$ hospital admissions for a range of QOF and non-QOF conditions; ${ }^{39}$ consultation rates in severe mental illness (SMI):40 prescribing in type 2 diabetes $;{ }^{41}$ and a composite indicator derived from QOF data on processes and outcomes of care in type 2 diabetes. ${ }^{42}$ Because of a high degree of study heterogeneity, the authors carried out a narrative synthesis. Table 1 summarises the design and results of primary research studies.

None of the relevant studies identified by the systematic reviews, or the primary studies published since 2012, examined the effect of the QOF on broader aspects of care or patient perspectives.

\section{Quality}

The systematic reviews were of good quality. Due to the nature of the intervention, the primary research studies were all beforeand-after studies using interrupted time series or difference-in-differences methods and, as such, were of good quality for observational studies. However, because of the study designs, the authors cannot be sure that the QOF was responsible for any change in outcomes.

\section{Findings}

Systematic reviews. The first systematic review concluded that the QOF had had a limited impact on health outcomes. ${ }^{15}$ The second systematic review concluded that the effect of pay-for-performance remained uncertain. ${ }^{16}$ The third systematic review concluded that there was limited evidence of the effects of financial incentives. ${ }^{17}$

Primary research. The study examining trends in mortality in the UK compared with other countries found no effect of the QOF, although the synthetic control approach ${ }^{43}$ adopted in the study required the use of conservative tests for statistical inference. ${ }^{38}$ The study examining emergency admissions before and after the introduction of the QOF found that the trend of increasing emergency hospital admission rates (which increased overall by 34\% between 2004 and 2010) was modestly lower for conditions incentivised in the QOF compared with conditions that were not incentivised in the QOF, by $3 \%$ in the first year rising to $8 \%$ in $2010 .{ }^{39}$ The difference was mainly driven by relative reductions in emergency admission rates for coronary heart disease.

The study examining consultation rates found a trend of increasing rates overall during the period, with a small step change in 2004; the rate of increase was greater in people with SMI than overall. ${ }^{40}$ The faceto-face consultation rate in SMI increased from about nine to 11 per patient per year from 2000 to 2011, and in other people it stayed stable at about five per patient per year over the same period. 


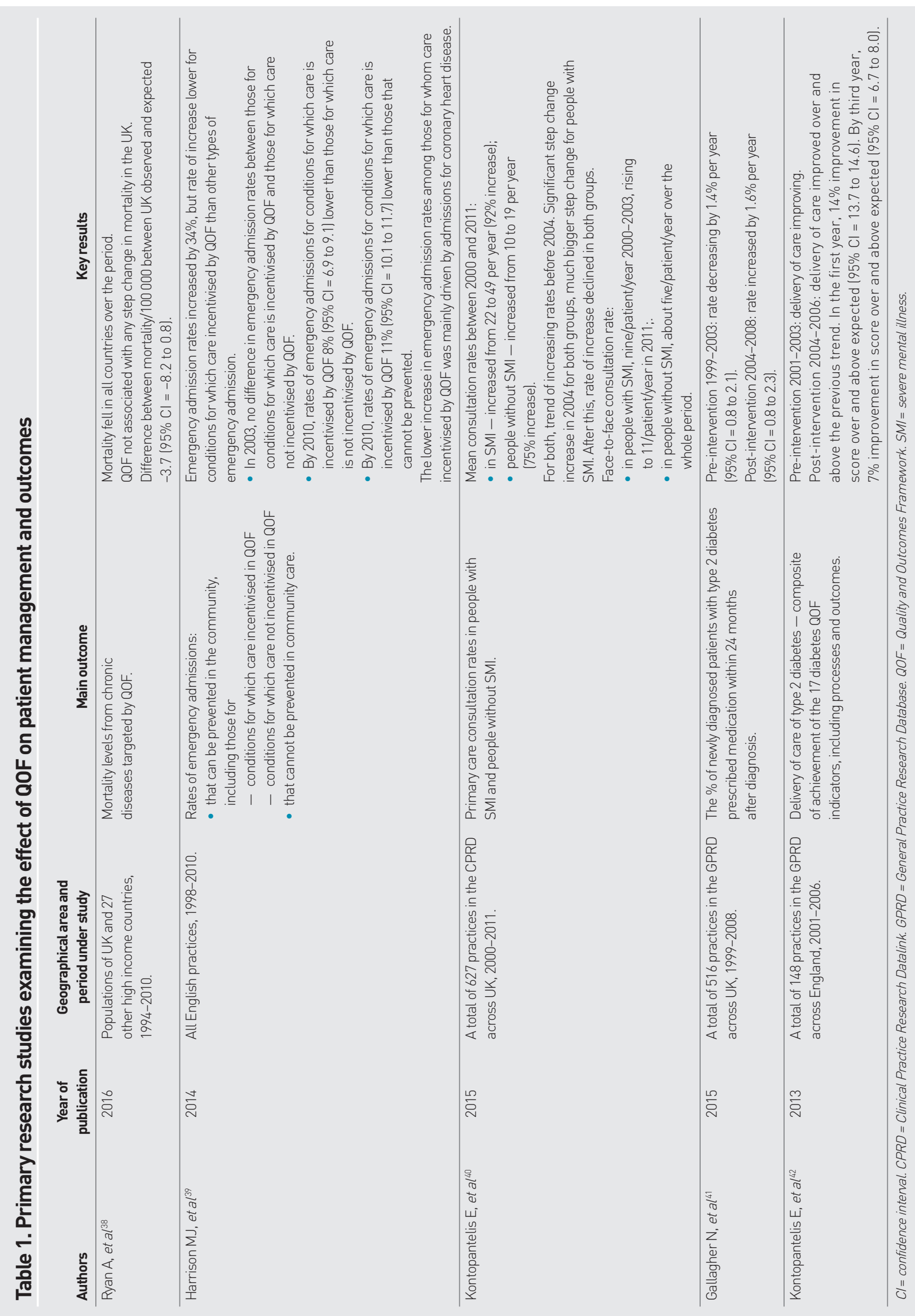


The study of prescribing in type 2 diabetes found a modest increase in prescribing of antidiabetic medication /changing the direction of the trend of decreasing initiation rates to increasing initiation rates) after the introduction of the QOF.41 The increase was sustained at a similar rate until 2008.

The study examining effects on a composite indicator of process and outcomes in type 2 diabetes found a modest improvement of $14 \%$ over and above the underlying trend in the first year after the introduction of the QOF, declining to $8 \%$ in the third year. ${ }^{42}$ Table 1 summarises the results of the studies.

\section{DISCUSSION}

\section{Summary}

The authors found evidence that the QOF may be associated with a modest reduction in emergency admission rates in long-term conditions, a modest increase in consultation rates in SMI, and modest improvements in certain limited aspects of the care of diabetes. They found no clear evidence that these changes have led to any effect on mortality. Because of the design of the studies, it is not possible to be sure that any of the positive effects seen are causally related to the QOF.

The authors found no evidence to suggest that the QOF influences, positively or negatively, other aspects of care, such as integration or coordination of care, holistic or personalised care, or self-care, nor any evidence of its effects on patients' quality of life, experience, or satisfaction.

The QOF is unlikely to advance progress towards the vision of the Five Year Forward View for the care of long-term conditions. To deliver the aims of the Five Year Forward View, the NHS should consider more broadly - beyond what is measured by the QOF - what constitutes high-quality primary care for people with long-term conditions, and consider managing performance on this basis. In the context of a demoralised primary care workforce, it is important also to consider ways other than financial incentives to motivate primary care teams to deliver high-quality care.

\section{Strengths and limitations}

To the authors' knowledge, this review is the first to have specifically addressed the effect of the QOF on those aspects of care for long-term conditions that are prioritised by national policy. As with any systematic review, the authors' conclusions are constrained by the limited quantity and quality of the primary research published to date. Although the search for quantitative research was comprehensive, the authors did not include qualitative research, which may provide other insights.

Research to date has not attempted to identify the effects of the QOF on any of the broader aspects of care for long-term conditions, having examined effects only on more easily measurable outcomes, for example, those collected as part of the QOF, or routinely available data on mortality, emergency admissions, consultation rates, and prescribing. The authors found no evidence of attempts to evaluate the QOF using validated measures of quality of care in general practice. Perhaps this is because defining and measuring quality of general practice is complex. ${ }^{44}$

The lack of effect of the QOF on mortality is surprising, given that the indicators are based on high-quality evidence of effectiveness of interventions. Why this is the case is not clear. The wider determinants of population health lincluding low income, experience of inequality or discrimination, or quality of air, education, housing, or work conditions ${ }^{45}$ ) may be much more important than the quality of care in determining mortality. Also, it is recognised that the effectiveness of interventions demonstrated in randomised controlled trials, which include highly selected study participants, is often diluted in routine clinical practice. ${ }^{46}$ Perhaps non-incentivised activities are more important in determining mortality in the patient population. It is also possible that practices misreport performance so as to exaggerate the quality of care, although there is little evidence that this is a significant problem. ${ }^{47}$

The authors found evidence that the QOF was associated with a modest slowing of the increase in emergency admissions for conditions for which care is incentivised by the QOF, and an increase in primary care attendances for people with serious mental illness. Whether the QOF is responsible for these is unclear; many other factors are likely to have influenced admission and attendance rates over the period, including changes in medical technology or access to other services, or national standards for management of long-term conditions. In any case, among interventions to prevent emergency admissions, pay-forperformance is unlikely to be one of the most effective. . $8,49^{\circ}$

It could be argued that some QOF indicators - in palliative care, cancer, SMI, dementia, and rheumatoid arthritis - incentivise multidisciplinary meetings, reviews, and care plans, considered necessary elements of holistic and 


\section{Funding}

This study was funded by the Policy Research Unit in Commissioning and the Healthcare System, and by the Department of Health. The views expressed are those of the researchers and not necessarily those of the Department of Health.

\section{Ethical approval}

Not applicable.

\section{Provenance}

Freely submitted; externally peer reviewed.

\section{Competing interests}

The authors have declared no competing interests.

\section{Acknowledgements}

The authors thank Ms Anna Peckham, consultant librarian, for her assistance in conducting the searches of electronic databases, Ms Linda Jenkins for her help with downloading and interpreting QOF reporting data, and Dr Mark Ashworth for his advice on interpreting the results.

\section{Open access}

This article is Open Access: CC BY-NC 4.0 licence (http://creativecommons.org/ licences/by-nc/4.0/).

\section{Discuss this article}

Contribute and read comments about this article: bjgp.org/letters

integrated care las set out in recent guidance from NICE). ${ }^{50}$ However, to achieve the indicators, practices are not required to demonstrate that their activities ensure that holistic or integrated care has been delivered.

\section{Implications for research and practice}

The authors found no convincing evidence that the QOF promotes better care and outcomes for people with long-term conditions. QOF may also have negative effects. If practices have achieved maximum or near maximum points under the scheme (which is true for most practices), they have little motivation to improve achievement further. It is likely that the QOF diverts practices and professionals from ways of providing high-quality primary care that is not QOF-related. Moreover, the QOF does not incentivise practices to improve care for patients with the most complex needs in primary care, because these are more likely to be excepted from the scheme..$^{51}$ Raising thresholds for achievement may be counterproductive - there is evidence that it leads to increased exception reporting, raising apparent achievement with no real increase in the desired activity. ${ }^{52}$

The Chief Executive of the NHS announced in October 2016 that the QOF would be phased out. ${ }^{53}$ What would happen to the quality of primary care if the QOF is completely abolished is not clear, although it seems unlikely that standards would drop significantly, because the activities rewarded in the QOF are now firmly embedded in practice. There is some limited evidence to suggest that performance did not fall following the withdrawal of certain individual indicators from the scheme. ${ }^{54}$ Abolishing the QOF may also allow practices to prioritise other activities, which could lead to better care.

The QOF provides a major component of practice income; if it were abolished, practices would need to be assured of a stable income. Losing this is likely to have detrimental effects on patient care and further worsen recruitment and retention in primary care, which is once again in a precarious position. .55

Alternative methods of rewarding good practice are being considered for new models of primary care. ${ }^{56}$ Any replacement for the QOF needs to consider the evidence of effectiveness of pay-for-performance in primary care, and the evidence of what motivates primary care professionals to provide high-quality care. ${ }^{57}$ 


\section{REFERENCES}

1. Sutcliffe D, Lester H, Hutton J, Stokes T. NICE and the quality and outcomes framework (QOF) 2009-2011. Qual Prim Care 2012; 20(1): 47-55.

2. Health and Social Care Information Centre. NHS payments to general practice, England, 2014-15. HSCIC, 2015. http://content.digital.nhs.uk/ catalogue/PUB18468 (accessed 11 Sep 2017)

3. Roland M, Guthrie B. Quality and outcomes framework: what have we learnt? BMJ 2016; 354: i4060.

4. Lester H, Campbell S. Developing quality and outcomes framework (QOF) indicators and the concept of 'QOFability'. Qual Prim Care 2010; 18(2): 103109

5. Doran T, Fullwood C, Kontopantelis E, Reeves D. Effect of financial incentives on inequalities in the delivery of primary clinical care in England: analysis of clinical activity indicators for the quality and outcomes framework. Lancet 2008; 372(9640): 728-736.

6. Roland M, Campbell S. Successes and failures of pay for performance in the United Kingdom. N Engl J Med 2014; 370(20): 1944-1949.

7. Kramer G. Payment for performance and the QOF: are we doing the right thing? Br J Gen Pract 2012; DOI: https://doi.org/10.3399/bjgp12X630151.

8. NHS England, Care Quality Commission, Public Health England, Health Education England, Monitor, Trust Development Authority. NHS five year forward view. London: NHS England, 2014

9. Royal College of General Practitioners. A blueprint for building the new deal for general practice in England. London: RCGP, 2015. http://www.rcgp.org uk/policy/rcgp-policy-areas/blueprint-for-general-practice.aspx laccessed 11 Sep 2017).

10. NHS England. General practice forward view, 2016. https://www.england.nhs. uk/gp/gpfv/ laccessed 11 Sep 2017).

11. Bostock N. GPC frustrated by NHS England failure to agree national QOF suspension. GP Online 2017; 3 Feb: http://www.gponline.com/gpc-frustratednhs-england-failure-agree-national-qof-suspension/article/1423088 laccessed 11 Sep 2017).

12. Higgins JPT, Altman DG, Gøtzsche PC, et al. The Cochrane Collaboration's tool for assessing risk of bias in randomised trials. BMJ 2011; 343: d5928.

13. National Heart, Lung, and Blood Institute. Quality assessment tool for beforeafter (pre-post) studies with no control group. https://www.nhlbi.nih.gov/ health-pro/guidelines/in-develop/cardiovascular-risk-reduction/tools/beforeafter (accessed 21 Aug 2017).

14. National Heart, Lung, and Blood Institute. Quality assessment of systematic reviews and meta-analyses. https://www.nhlbi.nih.gov/health-pro/guidelines/ in-develop/cardiovascular-risk-reduction/tools/sr_ma (accessed 11 Sep 2017)

15. Langdown C, Peckham S. The use of financial incentives to help improve health outcomes: is the quality and outcomes framework fit for purpose? A systematic review. J Public Health 2014; 36(2): 251-258.

16. Houle SKD, McAlister FA, Jackevicius CA, et al. Does performance-based remuneration for individual health care practitioners affect patient care? A systematic review. Ann Intern Med 2012; 157(12): 889-899.

17. Rashidian A, Omidvari AH, Vali Y, et al. Pharmaceutical policies: effects of financial incentives for prescribers. Cochrane Database Syst Rev 2015; 8: CD006731.

18. Alshamsan R, Lee JT, Majeed A, et al. Effect of a UK pay-for-performance program on ethnic disparities in diabetes outcomes: interrupted time series analysis. Ann Fam Med 2012; 10(3): 228-234.

19. Calvert M, Shankar A, McManus RJ, et al. Effect of the quality and outcomes framework on diabetes care in the United Kingdom: retrospective cohort study. BMJ 2009; 338: b1870.

20. Campbell SM, Reeves D, Kontopantelis E, et al. Effects of pay for performance on the quality of primary care in England. N Engl J Med 2009; 361(4): 368378 .

21. Coleman T, Lewis S. Hubbard R, Smith C. Impact of contractual financial incentives on the ascertainment and management of smoking in primary care. Addiction 2007; 102(5): 803-808

22. Doran T, Kontopantelis E, Valderas JM, et al. Effect of financial incentives on incentivised and non-incentivised clinical activities: longitudinal analysis of data from the UK Quality and Outcomes Framework. BMJ 2011; 342: d3590.

23. Gulliford MC, Ashworth M, Robotham D, Mohiddin A. Achievement of metabolic targets for diabetes by English primary care practices under a new system of incentives. Diabet Med 2007; 24(5): 505-511.
24. Hippisley-Cox J, Vinogradova Y, Coupland C. Time series analysis for selected clinical indicators from the quality and outcomes framework - 2001-2006. NHS digital, 2006. https://digital.nhs.uk/catalogue/PUB01968 laccessed 13 Sep 2017).

25. MacBride-Stewart SP. Elton R, Walley T. Do quality incentives change prescribing patterns in primary care? An observational study in Scotland. Fam Pract 2008; 25(1): 27-32.

26. McGovern MP, Boroujerdi MA, Taylor MW, et al. The effect of the UK incentive-based contract on the management of patients with coronary heart disease in primary care. Fam Pract 2008; 25(1): 33-39.

27. McGovern MP. Williams DJ, Hannaford PC, et al. Introduction of a new incentive and target-based contract for family physicians in the UK: good for older patients with diabetes but less good for women? Diabet Med 2008. 25(9): 1083-1089.

28. Millett C, Bottle A, Ng A, Majeed A. Pay for perfomance and the quality of diabetes management in individuals with and without co-morbid medical conditions. J R Soc Med 2009; 102(9): 369-377.

29. Millett C, Gray J, Saxena S, et al. Ethnic disparities in diabetes management and pay-for-performance in the UK: the Wandsworth Prospective Diabetes Study. PLoS Med 2007; 4(6): e191.

30. Millett C, Gray J, Saxena S, et al. Impact of a pay-for-performance incentive on support for smoking cessation and on smoking prevalence among people with diabetes. CMAJ 2007; 176(12): 1705-1710.

31. Millett C, Gray J, Wall M, Majeed A. Ethnic disparities in coronary heart disease management and pay for performance in the UK. J Gen Intern Med 2009; 24(1): 8-13.

32. Serumaga B, Ross-Degnan D, Avery AJ, et al. Effect of pay for performance on the management and outcomes of hypertension in the United Kingdom: interrupted time series study. BMJ 2011; 342: d108.

33. Simpson CR, Hannaford PC, Lefevre K, Williams D. Effect of the UK incentivebased contract on the management of patients with stroke in primary care. Stroke 2006; 37(9): 2354-2360.

34. Simpson CR, Hannaford PC, Ritchie LD, et al. Impact of the pay-forperformance contract and the management of hypertension in Scottish primary care: a 6-year population-based repeated cross-sectional study. $\mathrm{Br} \mathrm{J}$ Gen Pract 2011; DOI: https://doi.org/10.3399/bjgp11X583407.

35. Steel N, Maisey S, Clark A, et al. Quality of clinical primary care and targeted incentive payments: an observational study. Br J Gen Pract 2007; 57(539): 449-454.

36. Strong M, South G, Carlisle R. The UK Quality and Outcomes Framework payfor-performance scheme and spirometry: rewarding quality or just quantity? A cross-sectional study in Rotherham, UK. BMC Health Serv Res 2009; 9 108.

37. Vamos EP, Pape UJ, Bottle A, et al. Association of practice size and pay-forperformance incentives with the quality of diabetes management in primary care. CMAJ 2011; 183(12): E809-E816.

38. Ryan A, Krinsky S, Kontopantelis E, Doran T. Long-term evidence for the effect of pay-for-performance in primary care on mortality in the United Kingdom: a population study. Lancet 2016; 388(10041): 268-274.

39. Harrison MJ, Dusheiko M, Sutton M, et al. Effect of a national primary care pay-for-performance scheme on emergency hospital admissions for ambulatory care sensitive conditions: controlled longitudinal study. BMJ 2014; 349: g6423

40. Kontopantelis E, Olier I, Planner C, et al. Primary care consultation rates among people with and without severe mental illness: a UK cohort study using the Clinical Practice Research Datalink. BMJ Open 2015; 12(5) e008650.

41. Gallagher N, Cardwell C, Hughes C, O'Reilly D. Increase in the pharmacological management of type 2 diabetes with pay-for-performance in primary care in the UK. Diab Med 2015; 32(1): 62-68.

42. Kontopantelis E, Reeves D, Valderas JM, et al. Recorded quality of primary care for patients with diabetes in England before and after the introduction of a financial incentive scheme: a longitudinal observational study. BMJ Qual Saf 2013; 22(1): 53-64.

43. Dimick JB, Ryan AM. Methods for evaluating changes in health care policy: the difference-in-differences approach. JAMA 2014; 312(22): 2401-2402

44. Young RA, Roberts RG, Holden RJ. The challenges of measuring, improving, and reporting quality in primary care. Ann Fam Med 2017; 15(2): 175-182.

45. Marmot M, Bell R. Fair society, healthy lives. Public Health 2012; 126lSuppl 1): $S 4-S 10$. 
46. Ford I, Norrie J. Pragmatic trials. N Engl J Med 2016; 375(5): 454-463.

47. Ashworth M, Kordowicz M. Quality and outcomes framework: smoke and mirrors? Qual Prim Care 2010; 18(2): 127-131.

48. Purdey S, Huntley A. Predicting and preventing avoidable hospital admissions: a review. J R Coll Physicians Edinb 2013; 43(4): 340-344.

49. Wallace E, Smith SM, Fahey T, Roland M. Reducing emergency admissions through community based interventions. BMJ 2016; 352: h6817.

50. National Institute for Health and Care Excellence. Multimorbidity: clinical assessment and management. NG56. London: NICE, 2016. https://www.nice. org.uk/guidance/ng56 (accessed 11 Sep 2017).

51. Martin JL, Lowrie R, McConnachie A, et al. Physical health indicators in major mental illness: analysis of QOF data across UK general practice. $\mathrm{Br} J \mathrm{Gen}$ Pract 2014; DOI: https://doi.org/10.3399/bjgp14X681829

52. Kontopantelis E, Doran T, Gravelle H, et al. Family doctor responses to changes in incentives for influenza immunization under the UK Quality and Outcomes Framework pay-for-performance scheme. Health Serv Res 2012; 47(3 Pt 1): 1117-1136.
53. Matthews King A. QOF has reached the end of its useful life, says NHS chief Pulse 2016; 19 0ct: http://www.pulsetoday.co.uk/your-practice/qof/qof-hasreached-the-end-of-its-useful-life-says-nhs-chief/20033054.article laccessed 13 Sep 2017).

54. Kontopantelis E, Springate D, Reeves D, et al. Withdrawing performance indicators: retrospective analysis of general practice performance under UK quality and outcomes framework. BMJ 2014; 348: g330. [Erratum in BMJ 2014; 349: g7730.]

55. Roland M, Everington S. Tackling the crisis in general practice. BMJ 2016 ; 352: i942

56. NHS England. New care models. The multispecialty community provider (MCP) emerging care model and contract framework. 2016. https://www. england.nhs.uk/wp-content/uploads/2016/07/mcp-care-model-frmwrk.pdf laccessed 11 Sep 2017).

57. Peckham S, Marchand C, Peckham A. General practitioner recruitment and retention: an evidence synthesis. Project report. Policy Research Unit in Commissioning and the Healthcare System, University of Kent, 2016. https:// kar.kent.ac.uk/58788/ laccessed 11 Sep 2017). 


\section{Appendix 1. QOF indicators 2016/2017 relating to care of long-term conditions}

\begin{tabular}{|c|c|c|}
\hline Long-term condition & QOF code & Brief description of indicator \\
\hline Asthma & $\begin{array}{l}\text { AST001 } \\
\text { AST002 } \\
\text { AST003 } \\
\text { AST004 }\end{array}$ & $\begin{array}{l}\text { Register of patients with asthma } \\
\text { Percentage of patients with asthma and measures of variability or reversibility recorded } \\
\text { Percentage of patients with asthma who have had control assessed } \\
\text { Percentage of patients with asthma with record of smoking status }\end{array}$ \\
\hline Atrial fibrillation & $\begin{array}{l}\text { AF001 } \\
\text { AF006 } \\
\text { AF007 }\end{array}$ & $\begin{array}{l}\text { Register of patients with atrial fibrillation } \\
\text { Percentage of patients with atrial fibrillation in whom stroke risk has been assessed } \\
\text { Anticoagulant therapy in those with atrial fibrillation and high risk of stroke }\end{array}$ \\
\hline Cancer & $\begin{array}{l}\text { CAN001 } \\
\text { CAN003 }\end{array}$ & $\begin{array}{l}\text { Register of patients with cancer } \\
\text { Percentage of patients with cancer who have been reviewed }\end{array}$ \\
\hline Chronic kidney disease (CKD) & CKD001 & Register of patients with chronic kidney disease \\
\hline $\begin{array}{l}\text { Chronic obstructive } \\
\text { pulmonary disease (COPD) }\end{array}$ & $\begin{array}{l}\text { COPD001 } \\
\text { COPD002 } \\
\text { COPD003 } \\
\text { COPD004 } \\
\text { COPD005 } \\
\text { COPD007 }\end{array}$ & $\begin{array}{l}\text { Register of patients with COPD } \\
\text { Percentage of patients with COPD with diagnosis confirmed by post-bronchodilator spirometry } \\
\text { Percentage of patients with COPD who have had a review with assessment of breathlessness } \\
\text { Percentage of patients with COPD with a record of forced expiratory volume in } 1 \text { second (FEV1) } \\
\text { Percentage of patients with severe COPD with record of oxygen saturation } \\
\text { Percentage of patients with COPD who have had influenza immunisation }\end{array}$ \\
\hline Coronary heart disease (CHD) & $\begin{array}{l}\text { CHD001 } \\
\text { CHD002 } \\
\text { CHD005 } \\
\text { CHD007 }\end{array}$ & $\begin{array}{l}\text { Register of patients with CHD } \\
\text { Percentage of patients with CHD with blood pressure } 150 / 90 \mathrm{mmHg} \text { or less } \\
\text { Percentage of patients with CHD taking aspirin, an alternative antiplatelet therapy, or an anticoagulant } \\
\text { Percentage of patients with CHD who have had influenza immunisation }\end{array}$ \\
\hline Dementia & $\begin{array}{l}\text { DEM001 } \\
\text { DEM004 } \\
\text { DEM005 }\end{array}$ & $\begin{array}{l}\text { Register of patients with dementia } \\
\text { Percentage of patients with dementia whose care plan has been reviewed face-to-face } \\
\text { Percentage of patients with a new diagnosis of dementia with record of tests to exclude reversible cause }\end{array}$ \\
\hline Depression & DEP003 & Percentage of patients with new diagnosis of depression with review soon after diagnosis \\
\hline Diabetes mellitus & $\begin{array}{l}\text { DM002 } \\
\text { DM003 } \\
\text { DM004 } \\
\text { DM006 } \\
\text { DM007 } \\
\text { DM008 } \\
\text { DM009 } \\
\text { DM012 } \\
\text { DM014 } \\
\text { DM017 } \\
\text { DM018 }\end{array}$ & $\begin{array}{l}\text { Percentage of patients with diabetes with blood pressure } 150 / 90 \mathrm{mmHg} \text { or less } \\
\text { Percentage of patients with diabetes with blood pressure } 140 / 80 \mathrm{mmHg} \text { or less } \\
\text { Percentage of patients with diabetes with total cholesterol } 5 \mathrm{mmol} / \mathrm{l} \text { or less } \\
\text { Percentage of patients with diabetes and nephropathy taking angiotensin converting } \\
\text { enzyme inhibitors or angiotensin receptor blockers (ACEls or ARBs) } \\
\text { Percentage of patients with diabetes with glycosylated haemoglobin } 59 \mathrm{mmol} / \mathrm{mol} \text { or less } \\
\text { Percentage of patients with diabetes with glycosylated haemoglobin } 64 \mathrm{mmol} / \mathrm{mol} \text { or less } \\
\text { Percentage of patients with diabetes with glycosylated haemoglobin } 75 \mathrm{mmol} / \mathrm{mol} \text { or less } \\
\text { Percentage of QOF patients with diabetes with a record of a foot examination and foot risk classification } \\
\text { Patients newly diagnosed with diabetes referred to a structured education programme } \\
\text { Register of patients with diabetes } \\
\text { Percentage of patients with diabetes who have had influenza immunisation }\end{array}$ \\
\hline Epilepsy & EP001 & Register of patients with epilepsy \\
\hline Heart failure & $\begin{array}{l}\text { HF001 } \\
\text { HF002 } \\
\text { HF003 } \\
\text { HF004 }\end{array}$ & $\begin{array}{l}\text { Register of patients with heart failure } \\
\text { Percentage of patients with heart failure confirmed by an echocardiogram or by specialist assessment } \\
\text { Percentage of patients with heart failure taking ACEls or ARBs } \\
\text { Percentage of patients with heart failure taking ACEls or ARBs plus beta-blocker }\end{array}$ \\
\hline Hypertension & $\begin{array}{l}\text { HYP001 } \\
\text { HYP006 } \\
\text { CVD-PP001 }\end{array}$ & $\begin{array}{l}\text { Register of patients with hypertension } \\
\text { Percentage of patients with hypertension with blood pressure of } 150 / 90 \mathrm{mmHg} \text { or less } \\
\text { Percentage of patients with hypertension and high cardiovascular risk treated with statins }\end{array}$ \\
\hline Learning disability & LD003 & Register of patients with learning disability \\
\hline Mental health & $\begin{array}{l}\mathrm{MH0O1} \\
\mathrm{MH0O2} \\
\mathrm{MH} 003 \\
\mathrm{MH} 007 \\
\mathrm{MH008} \\
\mathrm{MH} 009 \\
\mathrm{MH} 010\end{array}$ & $\begin{array}{l}\text { Register of patients with serious mental health problems } \\
\text { Percentage of patients with serious mental health problems with comprehensive care plan } \\
\text { Percentage of patients with serious mental health problems with record of blood pressure } \\
\text { Percentage of patients with serious mental health problems with record of alcohol consumption } \\
\text { Percentage of women with serious mental health problems with cervical screening test performed } \\
\text { Percentage of patients on lithium therapy having renal and thyroid function monitored } \\
\text { Percentage of patients on lithium therapy with lithium levels in therapeutic range }\end{array}$ \\
\hline
\end{tabular}




\section{Appendix 1 continued. QOF indicators 2016/2017 relating to care of long-term conditions}

\begin{tabular}{|c|c|c|}
\hline Osteoporosis & $\begin{array}{l}\text { OSTOO2 } \\
\text { OSTO04 } \\
\text { OSTO05 }\end{array}$ & $\begin{array}{l}\text { Percentage of patients } 50-74 \text { with confirmed osteoporosis taking bone-sparing agent } \\
\text { Register of patients with osteoporosis } \\
\text { Percentage of patients aged }>75 \text { with osteoporosis taking bone-sparing agent }\end{array}$ \\
\hline People with palliative care needs & $\begin{array}{l}\text { PC001 } \\
\text { PC002 }\end{array}$ & $\begin{array}{l}\text { Register of patients in need of palliative care/support } \\
\text { Regular multidisciplinary case review meetings for people receiving palliative care }\end{array}$ \\
\hline Peripheral arterial disease & $\begin{array}{l}\text { PAD001 } \\
\text { PAD002 } \\
\text { PAD004 }\end{array}$ & $\begin{array}{l}\text { Register of patients with peripheral arterial disease } \\
\text { Percentage of patients with peripheral arterial disease with blood pressure } 150 / 90 \mathrm{mmHg} \text { or less } \\
\text { Percentage of patients with peripheral arterial disease taking aspirin or an alternative antiplatelet }\end{array}$ \\
\hline Rheumatoid arthritis & $\begin{array}{l}\text { RA001 } \\
\text { RA002 }\end{array}$ & $\begin{array}{l}\text { Register of patients with rheumatoid arthritis } \\
\text { Percentage of patients with rheumatoid arthritis who have had a face-to-face review }\end{array}$ \\
\hline $\begin{array}{l}\text { Stroke or transient } \\
\text { ischaemic attack (STIA) }\end{array}$ & $\begin{array}{l}\text { STIA001 } \\
\text { STIA003 } \\
\text { STIA007 } \\
\text { STIA008 } \\
\text { STIA009 }\end{array}$ & $\begin{array}{l}\text { Register of patients with STIA } \\
\text { Percentage of patients with STIA with blood pressure } 150 / 90 \mathrm{mmHg} \text { or less } \\
\text { Percentage of patients with non-haemorrhagic stroke or TIA taking antiplatelet agent, or anticoagulant } \\
\text { Percentage of patients with STIA referred for further investigation } \\
\text { Percentage of patients with STIA who have had influenza immunisation }\end{array}$ \\
\hline Several long-term conditions & $\begin{array}{l}\text { SMOK002 } \\
\text { SMOK005 }\end{array}$ & $\begin{array}{l}\text { Percentage of patients with long-term conditions with record of smoking status } \\
\text { Percentage of smokers with long-term conditions offered smoking cessation support }\end{array}$ \\
\hline
\end{tabular}

QOF = Quality and Outcomes Framework. 